\title{
Pemberdayaan Pedagang Pasar Tradisional dalam Pondok Komunitas Belajar di Sanggar Kegiatan Belajar Kabupaten Wonogiri
}

\author{
Marta Dwi Ningrum $^{1}$, S. Sujarwo ${ }^{1}$ * \\ ${ }^{1}$ Program Studi Pendidikan Luar Sekolah, Program Pascasarjana, Universitas Negeri \\ Yogyakarta. Jalan Colombo No. 1, Karangmalang, Yogyakarta 55281, Indonesia \\ * Corresponding Author. Email: sujarwo@uny.ac.id \\ Received: 14 July 2017; Revised: 24 October 2017; Accepted: 11 January 2018
}

\begin{abstract}
Abstrak
Penelitian ini bertujuan untuk mendiskripsikan pelaksanaan, hasil, dan faktor keberhasilan program pemberdayaan pedagang pasar tradisional dalam pondok komunitas belajar di SKB Kabupaten Wonogiri. Penelitian ini merupakan penelitian kualitatif dengan metode diskripsi. Teknik pengumpulan data yang digunakan yaitu wawancara, observasi, dan dokumentasi. Hasil penelitian menunjukkan bahwa (1) Pemberdayaan dapat dilakukan melalui kegiatan pelatihan yang disesuaikan dengan kebutuhan sasaran program. Pemberdayaan pedagang pasar tradisional dalam pondok komunitas belajar di SKB Kabupaten Wonogiri dilaksanakan melalui kegiatan pelatihan tata boga dan tata rias. (2) Hasil program pondok komunitas belajar meliputi penambahan pengetahuan dan ketrampilan, adanya kesadaran untuk menambah pengetahuan dan ketrampilan, penambahan relasi, dan kegiatan usaha.(3) Faktor keberhasilan program meliputi perencanaan program yang matang, motivasi belajar warga belajar yang tinggi, ketepatan materi dan metode pembelajaran, narasumber yang berkompeten dan penggunaan strategi pembelajaran yang tepat, dan sarana prasarana yang memadai.
\end{abstract}

Kata Kunci: komunitas belajar, pasar tradisional, pedagang, pemberdayaan masyarakat, Sanggar Kegiatan Belajar.

\section{Empowering Traditional Market Traders in the Learning Community Cottage in Community Learning Center (SKB) Wonogiri}

\begin{abstract}
This research aims to describe: the implementation, results, and success factors of the empowerment traditional market traders in the learning community cottage in SKB Wonogiri.This research is qualitative research with description method. Data collection techniques used were interviews, observation, and documentation. The results show that (1) Empowerment can be done through training activities tailored to the needs of program targets. The empowerment of traditional market traders in the community learning cottage in SKB Kabupaten Wonogiri is conducted through culinary and makeup training activities; (2) The results of the traditional market traders empowerment program in the community cottage of learn include expansion of knowledge and skills, their awareness to increase knowledge and skills, and increase relationships and enterpreneur activities.(3) Success factors include planning programs, sound program, the motivation to learning participants of high learning, precision materials and methods of learning, competent resource persons and the use of appropriate learning strategies, and adequate infrastructure.

Keywords: community empowerment, community learning, Community Learning Center (SKB), traders, traditional markets.

How to Cite: Ningrum, M., \& Sujarwo, S. (2017). Pemberdayaan pedagang pasar tradisional dalam pondok komunitas belajar di sanggar kegiatan belajar Kabupaten Wonogiri. JPPM (Jurnal Pendidikan dan Pemberdayaan Masyarakat), 4(2), 199-214. doi:http://dx.doi.org/10.21831/jppm.v4i2.13554
\end{abstract}

Permalink/DOI: http://dx.doi.org/10.21831/jppm.v4i2.13554

Copyright (c) 2017, JPPM, ISSN 2355-1615 (print), ISSN 2477-2992 (online) 


\section{Jurnal Pendidikan dan Pemberdayaan Masyarakat, 4 (2), November 2017 - 200 Marta Dwi Ningrum, S. Sujarwo}

\section{PENDAHULUAN}

Pasar merupakan salah satu pusat perekonomian rakyat, pusat penyediaan dan pemenuhan kebutuhan pokok yang berupa barang atau jasa, dan kebutuhan primer atau sekunder. Pasar tradisional sebagai tumpuan ekonomi masyarakat lokal yang berisi produk-produk lokal baik berupa sayur-sayuran, buah-buahan, beras, maupun kebutuhan pokok lainnya. Oleh karena itu, pasar tradisional merupakan wadah penting bagi penjualan produk-produk berskala ekonomi rakyat menengah ke bawah yang merupakan produk-produk hasil dari petani, nelayan maupun perajin lokal.

Kondisi pasar tradisional pada saat ini terancam oleh keberadaan pasar-pasar modern seperti supermarket, minimarket, maupun swalayan yang mengalami perkembangan yang sangat pesat. Menurut penelitian AC.Neilson pada tahun 2010 yang dipaparkan dalam Sadino dan Joesron (2014, p.206), sampai dengan tahun 2010 di Indonesia terdapat gerai modern sebanyak 13.240 terdiri dari: 358 convenience store, 11.569 minimarket, 1.146 supermarket, 141 hypermarket dan 26 warehouse clubs. Jumlah ini naik sebanyak 5,1\% dari jumlah tahun 2008 sebanyak 12.598 gerai. Sedangkan gerai tradisional berjumlah 2.520.757 buah (naik 2,08\% dari jumlah tahun 2008 sebanyak 2.469.465 gerai). Di sini terlihat bahwa persentase kenaikan jumlah gerai modern lebih tinggi dari pada gerai tradisional.

Hasil penelitian Sadino dan Joesron (2014, p.206) menjelaskan bahwa kondisi tersebut terjadi karena pasar tradisional masih kalah dengan pasar modern pada aspek karakteristik kondisi fisik dan area pelayanan. Pasar modern memiliki kondisi fisik yang lebih baik dan area pelayanan lebih luas dibandingkan dengan pasar tradisional. Penelitian Sarwoko (2008, p.108) memaparkan bahwa pasar modern berdampak pada perubahan keuntungan pedagang dimana keuntungan mengalami penurunan dalam satu tahun terakhir dibandingkan tahun-tahun sebelumnya.

Berdasarkan penjelasan tersebut, maka dapat diketahui bahwa perlunya kesiapan pasar tradisional untuk bersaing dengan pasar modern. Hasil penelitian Budiono (2005, p.70) menyatakan bahwa pendampingan dari pemerintah mampu meningkatkan pendapatan usaha dan keuntungan laba bersih bagi perempuan pedagang pasar tradisional. Pendampingan menjadi salah satu upaya yang dapat dilakukan oleh pemerintah untuk meningkatkan kualitas pedagang pasar tradisional. Program lain yang ditawarkan oleh pemerintah untuk mempertahankan pasar tradisional yaitu mengadakan revitalisasi pasar tradisional. Perubahan yang terlihat pada revitalisasi pasar yaitu adanya perbaikan pasar tradisional secara fisik.

Revitalization of tradisional markets towards the modern market in Indonesia has not been done optimally, this is because the stakeholders are likely to survive with their respective interests (Prastyawan, Suryono, Soeaidy, \& Muluk, 2015, p.5). Berdasarkan pendapat tersebut menyatakan bahwa revitalisasi pasar belum terlaksana dengan baik karena masih bergantung pada pemangku kepen-tingan. Revitalisasi pasar juga dilakukan oleh Kabupaten Wonogiri. Revitalisasi pasar Kabupaten Wonogiri tersebut berjalan baik dan menimbulkan berbagai dampak, baik dampak positif maupun negatif.

Berdasarkan data dari Badan Pusat Statistik Kabupaten Wonogiri tahun 2014, dapat diketahui adanya peningkatan minat masyarakat Kabupaten Wonogiri pada sektor perdagangan dan jasa sebagai lapangan pekerjaan utama masyarakat dari tahun ke tahun. Peningkatan jumlah penduduk yang bekerja pada sektor perdagangan dan jasa pada tahun 2014. Peningkatan tersebut berkisar 6,2 \% dari tahun sebelumnya. Dampak yang ditimbulkan dari revitalisasi Pasar Wonogiri tidak selalu positif, adanya pembangunan fisik Pasar Wonogiri yang memiliki 3 lantai tersebut tidak digunakan secara maksimal untuk kegiatan transaksi jual-beli produk-produk lokal Kabupaten Wonogiri.

Suasana lantai tiga yang lebih sepi dibandingkan lantai satu dan dua dijadikan sebagai tempat lokalisasi atau transaksi prostitusi Pekerja Seks Komersial (PSK) di Kabupaten Wonogiri. Permasalahan lain yang menjadi perhatian khusus adalah masih 


\section{Jurnal Pendidikan dan Pemberdayaan Masyarakat, 4 (2), November 2017 - 201 Marta Dwi Ningrum, S. Sujarwo}

rendahnya tingkat pendidikan masyarakat Kabupaten Wonogiri. Menurut data dari Badan Pusat Statistik Kabupaten Wonogori menjelaskan bahwa rata-rata lama sekolah masyarakat Kabupaten Wonogiri masih rendah. Rendahnya tingkat pendidikan juga terjadi pada pedagang pasar tradisional di Pasar Wonogiri. Menurut data dari Dinas Perindustrian, Perdagangan, Koperasi dan Usaha Kabupaten Wonogiri jumlah pedagang tradisional di Pasar Wonogiri sebanyak 279 pedagang dengan pendidikan rata-rata adalah Sekolah Menengah Pertama (SMP) dan Sekolah Menengah Atas (SMA). Pedagang Pasar Wonogiri mayoritas berasal dari Kabupaten Wonogiri yaitu berkisar 88,17 \%. Oleh karena itu, pentingnya peningkatan kualitas para pedagang Pasar Wonogiri demi meningkatkan kesejahteraan para pedagang pasar yang merupakan masyarakat asli Kabupaten Wonogiri.

Pasar Wonogiri yang berada di pusat Kabupaten Wonogiri ini menjadi pusat perbelanjaan yang tepat bagi masyarakat. Produk dan jasa yang ditawarkan juga bervariasi. Namun walaupun dalam kondisi demikian, Pasar Wonogiri dikelilingi oleh 2 swalayan besar yang juga menawarkan berbagai produk dan jasa yang tidak kalah menarik. Dengan demikian, untuk mempertahankan Pasar Wonogiri sebagai pusat perbelanjaan masyarakat Kabupaten Wonogiri dibutuhkan upaya untuk mempersiapkan para pedagang pasar agar mampu bersaing dengan pasar modern yang berada disekitarnya.

Berdasarkan permasalahan tersebut, SKB (SKB) Kabupaten Wonogiri sebagai lembaga yang bergerak di bidang pendidikan memiliki trobosan baru sebagai solusi permasalahan yang ada di masyarakat. SKB (SKB) Kabupaten Wonogiri yang bekerja sama dengan Dinas Perindustrian, Perdagangan dan Koperasi Kabupaten Wonogiri menyelenggarakan pondok komunitas belajar. Harapan dari pondok komunitas belajar tersebut sebagai wadah atau tempat untuk belajar berbagai pengetahuan dan ketrampilan bagi kalangan pedagang pasar. SKB (SKB) Kabupaten Wonogiri berusaha untuk membuka, melayani, dan memberikan kesempatan bagi masyarakat kalangan pedagang pasar untuk memperoleh layanan pendidikan sesuai dengan minat dan kebutuhannya.

Pemberdayaan merupakan salah satu upaya yang dapat dilakukan dalam meningkatkan kualitas manusia melalui pemberian pengetahuan dan ketrampilan agar manusia memiliki kemampuan dalam memenuhi kebutuhannya secara mandiri. Tujuan dari pemberdayaan yaitu untuk membentuk individu yang mampu mengetahui kebutuhannya dan mampu memenuhi kebutuhannya secara mandiri. Pemberdayaan menjadi sebuah strategi dalam memberikan kekuatan bagi masyarakat agar mampu hidup mandiri dalam memenuhi kebutuhannya.

Pemberdayaan dilakukan oleh SKB Kabupaten Wonogiri dengan membentuk pondok komunitas belajar sebagai tempat atau wadah untuk memberikan "daya" berupa pengetahuan, sikap, dan ketrampilan kepada pedagang pasar. Bentuk pemberdayaan yang dilaksanakan dalam program Pondok Komunitas Belajar yaitu program pelatihan.

Kegiatan pelatihan tersebut meliputi: pelatihan tata rias dan pelatihan tata boga. Pemilihan pelatihan tersebut disesuaikan pula dengan kebutuhan pasar maupun kebutuhan peluang kerja di Kabupaten Wonogiri. Pedagang pasar yang mayoritas berusia produktif tersebut diharapkan tidak hanya produktif dalam bidang perdagangan namun harus memiliki ketrampilan lain yang mampu menunjang kehidupannya. Pelatihan tata boga bertujuan untuk memberikan ketrampilan kepada pedagang pasar untuk selalu berinovasi dengan produkproduk olahan pangan yang dijajakannya sedangkan pelatihan tata rias bertujuan untuk memberikan pelayanan pendidikan kepada pedagang pasar yang disesuaikan dengan minat pedagang pasar, bahwa pedagang pasar juga mampu mengembangkan potensi yang mereka miliki.

Para pedagang dapat berdagang di pasar, dan setelah berdagang dapat membuka jasa tata rias di rumah, sehingga mampu menambah pendapatan keluarga. SKB Kabupaten Wonogiri mengadakan kerjasama dengan Dinas Perindustrian, Perdagangan 


\section{Jurnal Pendidikan dan Pemberdayaan Masyarakat, 4 (2), November 2017 - 202 Marta Dwi Ningrum, S. Sujarwo}

dan Koperasi dalam menyelenggarakan program Pondok Komunitas Belajar. Kepala Dinas Perindagkop Kabupaten Wonogiri menyatakan akan mendukung program Pondok Komunitas Belajar dan mengucapkan terimakasih kepada SKB Kabupaten Wonogiri atas kepeduliannya terhadap pedagang pasar tradisional di Pasar Wonogiri. Hal tersebut disampaikan oleh Kepala Perindagkop pada pembukaan Program Pondok Komunitas Belajar yang dilaksanakan pada tanggal 14 Desember 2015 (dokumen SKB, 2015).

Antusias pedagang pasar tradisional dalam mengikuti program ini meningkat dari periode sebelumnya. Menurut Kepala Pasar Wonogiri (2016) program Pondok Komunitas Belajar memiliki pengaruh positif bagi Pasar Wonogiri. Pertama, para pedagang pasar tradisional akan memiliki pengetahuan dan ketrampilan tambahan yang dapat menunjang kegiatan usahanya. Kedua, program Pondok Komunitas Belajar mampu meningkatkan kunjungan masyarakat ke Pasar Wonogiri. Program Pondok Komunitas pada tahun 2015 memiliki antusias yang tinggi sehingga warga belajar tidak hanya dari kalangan pedagang pasar namun juga dari masyarakat sekitar Pasar Wonogiri. Kondisi tersebut dapat menyebabkan kunjungan masyarakat ke Pasar Wonogiri meningkat.

Dengan demikian, perlunya suatu penelitian yang dapat mendiskripsikan pelaksanaan program pemberdayaan tersebut dengan menjelaskan kegiatan-kegiatan yang dilakukan dalam program pemberdayaan tersebut secara rinci. Harapannya, hasil dari penelitian mampu dijadikan sebuah acuan bagi lembaga lain dalam menyusun program pemberdayaan khususnya bagi kalangan pedagang pasar. Berangkat dari kondisi tersebut maka peneliti tertarik dengan pemberdayaan pedagang pasar yang diselenggarakan oleh SKB Kabupaten Wonogiri sehingga perlu dilakukan penelitian mengenai Pemberdayaan Pedagang Pasar Tradisional dalam Pondok Komunitas Belajar di SKB Kabupaten Wonogiri.

\section{METODE}

Jenis penelitian ini adalah penelitian kualitatif dengan metode diskriptif. Penelitian ini dilakukan di SKB Kabupaten Wonogiri. Latar penelitian ini merupakan program pemberdayaan pedagang pasar dalam pondok komunitas belajar di SKB Kabupaten Wonogiri. Lokasi pembelajaran program pemberdayaan tersebut berada di lantai 3 Gedung Pasar Wonogiri. Proses pembelajaran dilaksanakan dua pertemuan dalam seminggu pada masing-masing program pelatihan. Waktu pembelajaran disesuaikan dengan waktu luang peserta didik. Tutor dan fasilitator pada masing-masing program disediakan oleh SKB Kabupaten Wonogiri yang masing-masing memiliki kompetensi dan ketrampilan sesuai dengan bidang pelatihan. Fasilitator merupakan pamongpamong belajar di SKB Wonogiri yang memiliki ketrampilan dalam bidang pelatihan yang dilatihkan kepada pedagang pasar tradisional. Suasana belajar pada lantai tiga di Pasar Wonogiri terebut dibuat senyaman mungkin dan sarana prasarana pembelajaran pun sudah tersedia. Para pedagang pasar bisa memilih program pelatihan yang diminati dan dibutuhkan.

Unit analisis dalam penelitian ini adalah pedagang pasar tradisional dan masyarakat sekitar Pasar Wonogiri sebagai warga belajar program pondok komunitas belajar. Program pondok komunitas belajar merupakan salah satu program pendidikan yang diselenggarakan oleh SKB Kabupaten Wonogiri yang bertujuan untuk memberikan pelayanan pendidikan khususnya bagi kalangan pedagang pasar tradisonal di Pasar Wonogiri. Peneliti juga mengumpulkan informasi dari penyelenggara, pengelola dan fasilitator program tersebut untuk melengkapi data yang dibutuhkan. Aspek-aspek yang digali meliputi pelaksanaan program pemberdayaan pedagang pasar dalam pondok komunitas belajar, hasil program pemberdayaan pedagang pasar dalam pondok komunitas belajar, dan faktor keberhasilan program pemberdayaan pedagang pasar dalam pondok komunitas belajar.

Subyek penelitian terdiri atas penyelenggara, fasilitator, dan warga belajar 


\section{Jurnal Pendidikan dan Pemberdayaan Masyarakat, 4 (2), November 2017 - 203 Marta Dwi Ningrum, S. Sujarwo}

program Pondok Komunitas Belajar. Pemilihan subyek peneli-tian dilakukan dengan menggunakan teknik purposive sampling.

Data penelitian dikumpulkan melalui observasi (pengamatan), wawancara (interview) dan dokumentasi. Data penelitian ini dianalisis menggunakan teknik analisis kualiatatif seperti yang diungkapkan Miles, Huberman \& Saldana (2014, p.12) yaitu reduksi data, penyajian data, dan penarikan kesimpulan. Untuk pemeriksaan keabsahan data, peneliti menggunakan triangulasi sumber.

\section{HASIL DAN PEMBAHASAN}

Hasil

Pemberdayaan Pedagang Pasar Tradisional dalam Pondok Komunitas Belajar

Berdasarkan hasil penelitian dapat diketahui bahwa langkah-langkah pelaksanaan program pemberdayaan pedagang pasar tradisional tersebut meliputi perencanaan, pelaksanaan, evaluasi dan tindak lanjut. Perencanaan/persiapan, meliputi identifikasi kebutuhan dan penetapan jenis pelatihan, penentuan kepengurusan program, penjaringan warga belajar, penentuan waktu dan tempat pelaksanaan, penentuan narasumber dan materi pembelajaran, penentuan jadwal kegiatan, dan penentuan evaluasi kegiatan.

Komponen-komponen dalam pelaksanaan program Pondok Komunitas Belajar di SKB Kabupaten Wonogiri, meliputi: (1) narasumber, berasal dari pihak penyelenggara terdiri dari narasumber pelatihan tata boga dan narasumber pelatihan tata rias; (2) warga belajar, program pondok komunitas belajar ditujukan pada pedagang pasar tradisional Pasar Wonogiri dan masyarakat sekitar yang ingin belajar; (3) metode pembelajaran, narasumber menggunakan beberapa metode pembelajaran yaitu ceramah, praktik, dan diskusi;(4) media pembelajaran, narasumber menggunakan buku modul; (5) Materi pembelajaran, kegiatan pelatihan pada program ini termasuk dalam tingkat dasar yang harus diketahui pada masingmasing pelatihan; (6) strategi pembelajaran, kegiatan pelatihan dalam program ini menggunakan strategi pendidikan orang dewasa dan konsep learning by doing; dan
(7) proses pembelajaran, tahap-tahap proses pembelajaran yaitu persiapan, pemberian materi, kegiatan praktek, dan diskusi.

Monitoring dilaksanakan pada saat pelaksanaan setiap kegiatan pelatihan dan kegiatan evaluasi yang dilakukan adalah evaluasi praktik dan teori. Sedangkan kegiatan tindak lanjut dilakukan melalui konsultasi dan pembinaan kepada warga belajar setalah program selesai di selenggarakan.

Hasil Pemberdayaan Pedagang Pasar

Tradisional dalam Pondok Komunitas Belajar

Hasil program yang dirasakan oleh warga belajar setelah mengikuti kegiatan pelatihan pada program Pondok Komunitas Belajar meliputi: (1) penambahan pengetahuan dan ketrampilan, warga belajar merasakan/ memiliki pengetahuan dan ketrampilan baru terkait dengan masing-masing pelatihan yang diikuti; (2) adanya kesadaran untuk menambah pengetahuan dan ketrampilan, hal ini ditandai adanya warga belajar yang ingin melanjutkan pelatihan ke jenjang lebih tinggi; (3) penambahan relasi, warga belajar memperoleh teman baru baik dari temanteman pelatihan maupun dari pihak SKB Kabupaten Wonogiri.; dan (4) kegiatan usaha, warga belajar mulai memanfaatkan ketrampilan baru yang sudah dimilikinya.

Faktor-Faktor Keberhasilan Pemberdayaan Pedagang Pasar Tradisional dalam Pondok Komunitas Belajar

Hasil penelitian menunjukkan bahwa pelaksanaan program Pondok Komunitas Belajar berjalan dengan lancar dan sesuai rencana. Hasil program menunjukkan bahwa warga belajar sudah memanfaatkan ketrampilan yang dimiliki untuk kehidupannya. Indikator yang ditentukan oleh SKB Kabupaten Wonogiri dalam menilai keberhasilan program yaitu bahwa warga belajar sudah mampu melakukan ketrampilan yang diberikan dan mampu mengaplikasikannya dalam kehidupannya.

Keberhasilan program ini tercapai karena adanya berbagai faktor yang mempengaruhinya. Faktor-faktor yang mempengaruhi keberhasilan program ini adalah: adanya perencanaan program, motivasi bel- 


\section{Jurnal Pendidikan dan Pemberdayaan Masyarakat, 4 (2), November 2017 - 204 Marta Dwi Ningrum, S. Sujarwo}

ajar warga belajar tinggi, ketepatan materi dan metode pembelajaran, narasumber yang berkompeten dan penggunaan strategi pembelajaran yang tepat, serta sarana dan prasarana yang memadai

\section{Pembahasan}

Pemberdayaan atau empowerment berarti proses pemberian daya atau kekuatan kepada individu/kelompok. Saugi dan Sumarno (2015, p.227) menyatakan pemberdayaan masyarakat pada dasarnya merupakan strategi perubahan sosial secara terencana yang ditujukan untuk mengatasi masalah atau memenuhi kebutuhan masyarakat. Pernyataan tersebut sesuai dengan pendapat Miradj dan Sumarno (2014, p.104) menekankan pemberdayaan sebuah upaya untuk memberikan kekuatan atau daya untuk masyarakat dengan memanfaatkan kemampuan dan potensi yang dimiliki oleh masyarakat. Kasmel dan Anderson (2011, p.80o), menyatakan bahwa community empowerment is understood either as a process or as an outcome. Pemberdayaan dimaknai sebagai proses atau sebagai hasil.

Program Pondok Komunitas Belajar adalah salah satu upaya pemberdayaan yang berusaha memberikan pengetahuan dan ketrampilan kepada warga belajar. Bentuk kegiatan dari program tersebut adalah kegiatan pelatihan tata boga dan kegiatan pelatihan tata rias pengantin. Pondok yang berarti tempat dan komunitas adalah suatu kelompok maka dapat dimaksudkan bahwa Pondok Komunitas Belajar adalah suatu tempat yang digunakan untuk belajar oleh suatu kelompok tertentu.

Komunitas yang diharapkan adalah sasaran program yang meliputi pedagang pasar tradisional Pasar Wonogiri. Lantai 3 Pasar Wonogiri yang dulunya sebagai tempat yang memiliki image negatif ini dijadikan sebagai tempat belajar untuk kalangan pedagang pasar tradisional. Dengan demikian, dirumuskan tujuan Pondok Komunitas Belajar yaitu: (a) untuk memberikan pengetahuan dan ketrampilan bagi kalangan pedagang pasar tradisional Pasar Wonogiri sesuai kebutuhan. (b) memanfaatkan lantai 3 Pasar Wonogiri untuk kegiatan yang positif. (c) memotivasi pedagang pasar tradisional Pasar
Wonogiri agar terus meningkatkan pengetahuan dan ketrampian yang dimiliki.

Perumusan tujuan merupakan salah satu komponen penting dalam penyelenggaraan suatu program maupun pelatihan. Menurut Kamil (2010, p.18), tujuan yang dirumuskan akan menuntun penyelenggaraan program maupun pelatihan dari awal sampai akhir kegiatan, dari pembuatan rencana pembelajaran hingga evaluasi hasil belajar. Perumusan tujuan harus dirumuskan lebih spesifik, kongkret, dan jelas tentang apa yang harus dicapai dengan penyelenggaraan program maupun pelatihan tersebut. Dengan demikian, perumusan tujuan program Pondok Komunitas Belajar tersebut harus lebih kongkret dan jelas terkait dengan kompetensi atau ketrampilan yang ingin dicapai dalam penyelenggaraan Pondok Komunitas Belajar tersebut. Perumusan tujuan demikian akan lebih mudah memandu penyelenggara untuk merencanakan proses pembelajaran, materi, media hingga evaluasi hasil belajar.

Program Pondok Komunitas Belajar tersebut berupa penyelenggaraan pelatihan tata boga dan tata rias pengantin. Training is a performance development process to foster learning new techniques and methods to perform job with fullest efficiency and effectiveness. Successful training and development program assist the strategic requirement of the organization and also satisfies the individual needs of the people working in it. (Karim, Huda, \& Khan, 2012, p.141). Pelatihan tersebut diharapkan mampu memberikan pengetahuan dan ketrampilan yang akan mewujudkan warga belajar menjadi mandiri. Hal ini sesuai dengan konsep pemberdayaan yang diungkapkan oleh Sulistiyani (2004), bahwa pemberdayaan bertujuan untuk membentuk individu dan masyarakat menjadi mandiri.

Suparjan dan Suyatno (2003) menekankan bahwa pemberdayaan tidak dapat serta terwujud dengan cepat, perlu adanya beberapa tahap yang harus dilalui, dimulai dari penyadaran masyarakat terkait posisimya dalam sosial dan politik, peningkatan kapasitas hingga pemberdayaan tersebut terwujud. Berdasarkan hasil penelitian, program Pondok Komunitas Belajar ini memiliki 


\section{Jurnal Pendidikan dan Pemberdayaan Masyarakat, 4 (2), November 2017 - 205 Marta Dwi Ningrum, S. Sujarwo}

berbagai tahap yang meliputi persiapan, pelaksanaan, monitoring dan evaluasi, serta tindak lanjut program. Tahap persiapan terdapat kegiatan perekrutan warga belajar. Penyelenggara memberikan sosialisasi program kepada sasaran program terkait dengan pelaksanaan program, latar belakang diadakannya program dan kegiatan yang ditawarkan dalam program tersebut. Warga belajar mendaftarkan dirinya secara langsung tanpa adanya paksaan dari SKB Kabupaten Wonogiri. Harapannya, warga belajar yang mengikuti kegiatan dalam program tersebut adalah warga belajar yang memiliki motivasi yang tinggi untuk belajar.

Penjaringan warga belajar menjadi kunci yang dapat menentukan keberhasilan langkah selanjutnya. Kamil (2010, p.17) menjelaskan bahwa dalam rekruitmen atau penjaringan warga belajar ini penyelenggara diharapkan menetapkan beberapa persyaratan yang harus dipenuhi oleh peserta terutama yang berhubungan dengan karakteristik peserta yang bisa mengikuti pelatihan. Berdasarkan penjelasan tersebut dapat diketahui bahwa penyelenggara program maupun pelatihan perlu membuat kriteria atau persyaratan warga belajar yang mengikuti program maupun pelatihan yang akan dilaksanakan.

Penyelenggara program Pondok Komunitas Belajar belum merumuskan kriteria atau persyaratan warga belajar yang dapat mengikuti program tersebut. Semua calon warga belajar dapat mendaftar secara langsung dan diterima menjadi warga belajar apabila kuota yang disiapkan pada masingmasing pelatihan belum terpenuhi.

Penyelenggara program Pondok Komunitas Belajar juga perlu mengidentifikasi kebutuhan warga belajar yang sudah mendaftar. Penjaringan warga belajar yang dilakukan dalam Pondok Komunitas Belajar tersebut memungkinkan warga belajar yang mendaftar tidak sesuai dengan sasaran program yang terindeintifikasi kebutuhannya. Dengan demikian, kegiatan identifikasi kebutuhan lebih baik dilaksanakan setelah kuota warga belajar terpenuhi.

Pada tahap pelaksanaan program, penyelenggara mengadakan 2 kegiatan pelatihan berupa pelatihan tata boga dan pelatihan tata rias pengantin. Pelaksanaan pada masing-masing kegiatan tersebut memberikan pengetahuan dan ketrampilan kepada warga belajar. Dengan demikian, adanya proses transformasi yaitu narasumber memberikan pengetahuan dan ketrampilan kepada warga belajar dan warga belajar menerima pengetahuan dan ketrampilan tersebut. Hal ini sesuai dengan pendapat Sulistyani (2004) bahwa dalam pemberdayaan terdapat tahap transformasi. Proses pembelajaran dilakukan dengan 3 metode pembelajaran, yaitu: ceramah, praktek, dan diskusi.

Berdasarkan hasil wawancara diketahui bahwa metode-metode pembelajaran yang digunakan sudah tepat dan sesuai dengan materi yang diberikan berupa teori dan praktik. Materi yang diberikan mudah dipelajari karena proporsi materi lebih banyak praktek dibandingkan teori yang memiliki presentase 80\%:20\%. Warga belajar dapat mempraktekkan materi yang didapatkan secara langsung, Hal tersebut sejalan dengan konsep learning by doing, yaitu belajar dengan melakukannya. Warga belajar memahami segala sesuatu dengan melakukannya. Strategi pembelajaran learning by doing sangat sesuai digunakan dalam program pemberdayaan khusunya pada kegiatan pelatihan. Warga belajar yang tergolong orang dewasa juga akan merasa lebih paham apabila mempraktekkan materi yang disampaikan.

Strategi pembelajaran yang digunakan bagi narasumber sudah sesuai dengan kebutuhan warga belajar. Sarana dan prasarana terkait dengan peralatan dan bahan yang digunakan dalam kegiatan pelatihan juga sudah memenuhi kebutuhan warga belajar. Namun, dalam proses pembelajaran perlu diperhatikan terkait dengan perbandingan jumlah warga belajar dengan narasumber. Jumlah narasumber dalam masing-masing kegiatan pelatihan dalam program pondok komunitas belajar hanya berjumlah 1 orang dan jumlah warga belajar 20-24 orang. Menurut Kementrian Kesehatan RI (2014, p.23) perbandingan jumlah ideal fasilitator dalam menangani peserta program pelatihan adalah 1:6. Berdasarkan penjelasan tersebut, dapat diketahui bahwa perbandingan jumlah 


\section{Jurnal Pendidikan dan Pemberdayaan Masyarakat, 4 (2), November 2017 - 206 Marta Dwi Ningrum, S. Sujarwo}

narasumber dan warga belajar sebaiknya 1:6, terutama pada kegiatan pelatihan.

Perbandingan jumlah warga belajar dan narasumber perlu diperhatikan agar materi yang diberikan mudah untuk dipahami oleh warga belajar. Dengan demikian, narasumber yang dibutuhkan dalam masingmasing pelatihan ini perlu disesuaikan dengan jumlah warga belajar yang diampu. Jumlah narasumber program Pondok Komunitas Belajar perlu ditambah atau narasumber perlu dibantu oleh 2-3 orang pemandu untuk membantu narasumber dalam memandu warga belajar khususnya pada kegiatan praktek. Pemandu harus disesuaikan dengan kompetensi yang dibutuhkan pada masing-masing kegiatan pelatihan,

Tahap terakhir menurut teori yang akan terjadi pada proses pemberdayaan adalah tahap peningkatan kemampuan intelektual, kecakapan-keterampilan sehingga terbentuklah inisiatif dan kemampuan inovatif untuk mengantarkan pada kemandirian. Tahap tersebut terjadi ketika warga belajar sudah merasakan manfaat secara langsung terhadap pengetahuan dan ketrampilan yang sudah dikuasai. Warga belajar mampu memanfaatkan kemampuan yang dimiliki untuk kegiatan usaha. Berdasarkan penelitian yang didapat, kegiatan usaha yang dilakukan oleh warga belajar meliputi: membuka jasa tata rias pengantin, membuka salon, menjual aneka kue, dan membuka pemesanan snack. Dengan demikian, hasil program yang dirasakan langsung oleh warga belajar adalah memotivasi warga belajar untuk menggunakan ketrampilan yang dimiliki untuk kegiatan usaha.

Warga belajar mencoba untuk merintis usaha dengan menggunakan ketrampilan tersebut. Hal ini sesuai dengan tahap dalam proses pemberdayaan yaitu adanya inisiatif dan kemampuan inovatif untuk mengantarkan pada kemandirian, warga belajar memiliki inisiatif untuk melakukan kegiatan usaha dengan memanfaatkan kemampuan yang sudah dimiliki setelah mengikuti kegiatan pelatihan ini. Kegiatan usaha ini mampu membuat warga belajar mandiri dalam memenuhi kebutuhannya, artinya warga belajar memiliki tambahan pendapatan untuk memenuhi kebutuhannya secara mandiri.

Berdasarkan penjelasan tersebut maka dapat diketahui bahwa tahap-tahap yang dilalui dalam pelaksanaan hingga hasil program Pondok Komunitas Belajar sejalan dengan tahap-tahap proses pemberdayaan. Program Pondok Komunitas Belajar adalah suatu upaya dalam pemberdayaan bagi suatu komunitas tertentu. Komunitas yang dimaksud adalah warga belajar yang mengikuti kegiatan ini yaitu para pedagang pasar dan masyarakat sekitar di Pasar Wonogiri.

Evans, Kurantowicz, \& Lucio (2016, p.36) yang menyatakan community is presented as responsible for all things. The State, as provider of welfare, transfers this responsibility to the community. Komunitas yang dimaksudkan adalah tidak hanya sebatas administratif saja namun suatu kelompok yang memiliki tujuan dan cara untuk melakukannya. Komunitas yang diharapkan dalam Pondok Komunitas Belajar adalah masing-masing warga belajar yang berkumpul dengan niat dan tujuan yang sama dan untuk mencapai tujuan tersebut dengan cara yang sama. Warga belajar yang mengikuti program ini memiliki tujuan yang sama yaitu ingin belajar terkait pengetahuan dan ketrampilan yang ditawarkan oleh SKB dan cara yang dilakukan dalam mencapai tujuan tersebut sama yaitu mengikuti proses pembelajaran yang sudah disepakati bersama antara narasumber dan warga belajar.

Komunitas yang dibentuk oleh program Pondok Komunitas Belajar diharapkan mampu menjadi komunitas belajar atau learning community. Menurut Boshier dalam Shofwan (2013, p.25) menyatakan learning community is the nation of learning society stems from third force psychology, widespread disenchantment with traditional education, the writing of educational radicals such as Illich, Reimer, Goodman, and Freire, and the unprecedented transformation wrought by economic and social changes associated with evolving technology. Komunitas belajar atau learning community dipandang sebagai pendidikan alternatif yang memberikan pelayanan pendidikan di luar persekolahan. Sejalan dengan pendapat tersebut 


\section{Jurnal Pendidikan dan Pemberdayaan Masyarakat, 4 (2), November 2017 - 207 Marta Dwi Ningrum, S. Sujarwo}

Zubaidi (2006, p.131) menyatakan bahwa konsep pendidikan alternatif berbasis komunitas sama dengan "konsep pendidikan berbasis masyarakat yang menjadi sebuah gerakan penyadaran untuk terus belajar sepanjang hayat dalam mengatasi tantangan kehidupan yang berubah-ubah semakin berat. Komunitas belajar pada penelitian ini berkaitan dengan suatu wadah yang disiapkan sebagai pendidikan alternatif bagi masyarakat khususnya para pedagang pasar tradisional di Kabupaten Wonogiri agar memperoleh layanan berupa pemberian pengetahuan dan ketrampilan yang dibutuhkan oleh para pedagang tersebut. Pasar Wonogiri lantai 3 diharapkan menjadi tempat belajar bagi komunitas tersebut. Harapan dari program Pondok Komunitas Belajar adalah warga belajar memiliki motivasi untuk selalu belajar dengan mencari informasi yang dibutuhkan untuk memenuhi kebutuhannya.

Berdasarkan penelitian yang sudah dilakukan, diketahui bahwa warga belajar sudah memiliki pengetahuan dan ketrampilan sesuai dengan pelatihan yang diikuti namun belum semua warga belajar memiliki motivasi untuk terus belajar. Penyelenggara harus terus memotivasi warga belajar untuk terus meningkatkan kemampuan yang dimiliki warga belajar tersebut. Penyelenggara dapat melakukan hal tersebut melalui kegiatan monitoring dan evaluasi pada kegiatan tindak lanjut program. Kegiatan monitoring dan evaluasi tidak hanya dilaksanakan dalam proses pembelajaran. Kegiatan monitoring dan evaluasi diharapkan dilaksanakan pada pra pelaksanaan, pelaksanaan, dan pasca pelaksanaan program.

Evaluasi program merupakan kegiatan untuk menilai seluruh kegiatan pelatihan dari awal sampai akhir, dan hasilnya menjadi masukan bagi pengembangan pelatihan selanjutnya (Kamil, 2010, p.19). Evaluasi program dilaksanakan dari awal hingga akhir dan hasil evaluasi dapat dijadikan sebagai bahan pertimbangan dalam mengambil keputusan. Penyelenggara mampu mengidentifikasi faktor pendukung dan penghambat program mulai dari awal hingga akhir penyelengaraan program. Kegiatan evaluasi yang dilaksanakan oleh penyelenggara program pondok komunitas belajar masih pada evaluasi pembelajaran dan belum pada kegiatan evaluasi program. Penyelenggara perlu mengadakan kegiatan evaluasi awal dan setelah program dilaksanakan.

Mappa dalam Kamil (2010, p.62), menjelaskan bahwa aspek-aspek yang perlu dinilai pada evaluasi program adalah komponen program dan penyelenggaraan program. Komponen-komponen program meliputi masukan, proses dan hasil program, sedangkan penyelenggaraan program menyangkut kelembagaan, perencanaan, pelaksanaan dan pembinaan, efisiensi ekonomik, serta dampak dalam keseluruhan program. Dengan demikian, penyelenggara program pondok komunitas belajar perlu mengevaluasi aspekaspek tersebut. Kegiatan evaluasi yang dilaksanakan masih pada evaluasi hasil belajar yang dilakukan pada akhir pelatihan.

Penyelenggara perlu mengevaluasi komponen program meliputi masukan, perencanaan, pelaksanaan, proses dan pembinaan serta dampak keseluruhan program. Hasil dari evaluasi dapat dijadikan sebagai bahan referensi dalam membuat kegiatan tindak lanjut. Dengan demikian, penyelenggara mengetahui hal-hal yang perlu diperbaiki maupun dipertahankan dalam pelaksanaan pemberdayaan pedagang pasar tradisional dalam program pondok komunitas belajar.

Berdasarkan pembahasan pelaksanaan program Pondok Komunitas Belajar dapat diketahui bahwa pelaksanaan program berjalan dengan lancar. Program tersebut merupakan salah satu upaya pemberdayaan masyarakat yang memberikan pengetahuan dan ketrampilan yang dibutuhkan oleh masyarakat. Pelaksanaan program tersebut menyelenggarakan dua kegiatan pelatihan yaitu pelatihan tata boga dan pelatihan tata rias pengantin. Pondok Komunitas Belajar sebagai wadah untuk melayani masyarakat khususnya bagi kalangan pedagang pasar dan masyarakat sekitar Pasar Wonogiri. Harapan diadakannya Pondok Komunitas Belajar membentuk komunitas atau sekelompok yang memiliki kesadaran penuh untuk meningkatkan kualitas dirinya.

Tahap-tahap pada pelaksanaan program Pondok Komunitas sudah sejalan 


\section{Jurnal Pendidikan dan Pemberdayaan Masyarakat, 4 (2), November 2017 - 208 \\ Marta Dwi Ningrum, S. Sujarwo}

dengan tahap pemberdayaan. Namun, masih terdapat hal-hal yang perlu diperbaiki dalam pelaksanaan program pondok komunitas belajar ini. Perbaikan tersebut diperlukan dalam kegiatan perumusan tujuan, penjaringan warga belajar, pemenuhan jumlah narasumber, serta kegiatan monitoring dan evaluasi program pondok komunitas belajar. Perbaikan dalam pelaksanaan program pondok komunitas belajar tersebut diharapkan mampu mewujudkan pemberdayaan pedagang pasar tradisional yang lebih baik dari pelaksanaan pemberdayaan pada periode ini.

Hasil program pondok komunitas belajar di SKB Kabupaten Wonogiri berkaitan dengan kemampuan dan pengaruh program tersebut terhadap warga belajar. Program Pondok Komunitas Belajar adalah suatu upaya dalam program pemberdayaan. Pemberdayaan merupakan pengalihan kekuasaan, pengetahuan, maupun daya kepada suatu individu atau kelompok tertentu yang dipandang lemah agar mereka mampu mandiri, namun pemberdayaan tidak hanya sekedar pengalihan kekuasaan dan daya, pemberdayaan menunjuk pada keadaan atau hasil ingin dicapai oleh perubahan sosial.

Hasil yang dicapai dalam pemberdayaan yaitu adanya peningkatan kemampuan berupa pengetahuan dan ketrampilan yang nantinya mampu mencapai perubahan sosial. Pemberdayaan merupakan usaha untuk mengalihkan "daya” kepada sasaran program yang harapannya sasaran program akan berdaya. Berdasarkan hasil penelitian diketahui bahwa salah satu perubahan pada warga belajar setelah mengikuti program ini yaitu adanya penambahan pengetahuan dan keterampilan. Warga belajar memiliki ketrampilan dalam bidang tata boga yaitu membuat kue dan ketrampilan dalam bidang tata rias yaitu tata rias pengantin. Perubahan tersebut terlihat ketika warga belajar mampu mempraktekkan semua materi yang diberikan oleh narasumber. Salah satu tanda bahwa warga belajar dapat memenuhi semua indikator tersebut yaitu warga belajar menerima sertifikat dari SKB Kabupaten Wonogiri.

Pemberdayaan tidak hanya berkaitan dengan pengalihan pengetahuan dan keterampilan kepada masyarakat. Menurut Ife \& Tesoriero pemberdayaan berkaitan dengan pengembangan masyarakat. Pernya-taan tersebut juga senada dengan pendapat yang dinyatakan oleh Sulistiyani (2004) yang menjelaskan bahwa pada hakikatnya pemberdayaan merupakan penciptaan suasana atau iklim yang memungkinkan potensi masyarakat berkembang (enabling).

Hasil program yang berkaitan dengan pengembangan masyarakat yaitu berhubungan dengan adanya motivasi warga belajar untuk mengembangkan kemampuan yang dimiliki. Program Pondok Komunitas Belajar berusaha memberikan motivasi kepada warga belajar untuk terus belajar dan meningkatkan kualitas dirinya dan mencari berbagai pengetahuan dan informasi yang dibutuhkan. Kegiatan pelatihan yang diselenggarakan dalam program ini bertujuan untuk memicu agar tumbuhnya rasa ingin tahu pada masing-masing warga belajar.

Warga belajar merasa belum puas dengan materi yang didapatkan, dalam program ini, khususnya dirasakan oleh warga belajar pada kegiatan pelatihan tata rias pengantin. Rasa tidak puas yang dimaksudkan adalah merasa kurang dengan materi yang diberikan dan ingin mempelajari materi tersebut lebih lanjut. Warga belajar mengikuti program kursus swadaya untuk memperdalam materi yang dipelajari sebelumnya. Motivasi yang dimiliki warga belajar yang ingin melanjutkan kursus tersebut yaitu untuk memperdalam dan menguasai berbagai teknik tata rias dan salon yang diharapkan setelah memiliki pengetahuan tersebut maka mereka dapat membuka usaha salon dan tata rias pengantin.

Hasil penelitian menunjukkan bahwa antusias warga belajar untuk terus belajar tinggi. Antusiasme tersebut muncul dikarenakan adanya ketertarikan warga belajar terhadap materi yang disampaikan dan adanya keinginan untuk terus meningkatkan pengetahuan dan ketrampilan yang dimiliki. Dengan demikian, dapat diketahui bahwa kesadaran untuk belajar sudah tumbuh dalam diri warga belajar. Dengan demikian, diketahui bahwa program Pondok Komunitas Belajar menyediakan kegiatan pelatihan sesuai dengan potensi dan minat masyarakat. 


\section{Jurnal Pendidikan dan Pemberdayaan Masyarakat, 4 (2), November 2017 - 209 Marta Dwi Ningrum, S. Sujarwo}

Hasil pemberdayaan akan tercapai apabila proses pemberdayaan tersebut dilakukan dengan benar. Menurut Soetomo (2013, p.88) menjelaskan bahwa proses pemberdayaan akan terjadi apabila terdapat dua unsur dalam proses tersebut. Unsurunsur tersebut meliputi pemberian kewenangan dan pengembangan kapasitas masyarakat. Kedua unsur tersebut tidak dapat dipisahkan, oleh karena itu apabila masyarakat telah memperoleh kewenangan namun tidak atau belum mempunyai kapasitas untuk menjalankan kewenangan tersebut maka hasilnya juga tidak optimal. Penjelasan tersebut sejalan dengan pendapat Suharto (2010, p.59) bahwa proses pemberdayaan adalah serangkaian kegiatan untuk memperkuat kekuasaan atau keberdayaan kelompok lemah dalam masyarakat, termasuk individu yang mengalami kemiskinan.

Pendapat tersebut menekankan bahwa proses pemberdayaan memperhatikan tiga hal yaitu: pemberian kewenangan, pemberian kapasitas masyarakat, dan memperkuat kekuasaan atau keberdayaan kelompok yang lemah. Berdasarkan pendapat tersebut maka dapat diketahui bahwa pemberdayaan akan tercapai apabila sasaran program memiliki kewenangan, kapasitas/kemampuan, dan sasaran program mampu menggunakan kapasitas yang dimilikinya untuk memperkuat kekuasaannya. Kekuasaan dalam hal ini adalah kewenangan dirinya untuk menentukan masa depannya secara mandiri. Hal ini senada dengan pendapat Sulistiyani (2004) yang menjelaskan bahwa harapan dari pemberdayaan yaitu membentuk individu dan masyarakat menjadi mandiri.

Kemandirian tersebut meliputi kemandirian berpikir, bertindak, dan mengendalikan apa yang mereka lakukan. Kemandirian masyarakat ditandai oleh kemampuan untuk memikirkan, memutuskan, serta melakukan sesuatu yang dipandang tepat demi mencapai pemecahan masalah-masalah yang dihadapi dengan mempergunakan daya kemampuan yang terdiri atas kemampuan kognitif, konatif, psikomotorik, afektif, dan mengerahkan sumberdaya yang dimiliki oleh lingkungan internal masyarakat tersebut. Berdasarkan hasil penelitian diketahui bahwa hasil program yang terlihat setelah warga belajar mengikuti kegiatan pelatihan yaitu adanya kegiatan usaha. Kegiatan usaha yang dilakukan meliputi: membuka jasa tata rias pengantin, membuka salon, menjual aneka kue, dan membuka pemesanan snack.

Kegiatan usaha tersebut merupakan bentuk kemandirian yang dicapai oleh warga belajar. Warga belajar berani memutuskan sendiri untuk memanfaatkan ketrampilan baru ya-ng sudah dimilikinya untuk memulai kegiatan usaha. Hasil wawancara yang didapatkan oleh peneliti menunjukkan bahwa warga belajar merasa senang ketika mereka mampu memanfaatkan hasil dari pelatihan yang diikuti secara langsung. Keterampilan yang dimiliki merupakan keterampilan baru namun dengan ketrampilan tersebut, warga belajar sudah memiliki motivasi untuk melakukan kegiatan usaha. Warga belajar mengakui bahwa hasil dari kegiatan usaha tersebut dapat meningkatkan pendapatannya sehingga mereka mampu memenuhi kebutuhannya secara mandiri. Hal ini menggambarkan bahwa program Pondok Komunitas Belajar yang diselenggarakan oleh SKB Kabupaten Wonogiri mampu memberikan motivasi kepada warga belajar untuk membentuk individu yang mandiri.

Berbeda dengan pendapat Sulistiyani, Suparjan menyampaikan bahwa indikator keberhasilan program pemberdayaan hanya dapat dilihat dengan adanya community awareness. Adanya kesadaran komunitas ini diharapkan dapat mengubah pemberdayaan yang bersifat penguasaan menjadi bentuk kemitraan serta mengeliminir terbentuknya solidaritas komunal semu pada masyarakat (Suparjan \& Suyatno, 2003, pp.43-44).

Pendapat Suparjan tersebut menekankan bahwa indikator keberhasilan pada program pemberdayaan adalah adanya rasa solidaritas dan kesadaran suatu kelompok untuk saling bekerja sama, bermitra, dan tidak saling menguasai. Hasil program yang dirasakan oleh warga belajar pada program ini yaitu penambahan relasi. Warga belajar pada kegiatan pelatihan memiliki teman baru dan pengalaman baru. Penambahan relasi ditandai adanya bertambahnya jumlah teman dan link untuk kegiatan usaha. Warga belajar yang beberapa dari mereka adalah 


\section{Jurnal Pendidikan dan Pemberdayaan Masyarakat, 4 (2), November 2017 - 210 Marta Dwi Ningrum, S. Sujarwo}

pedagang pasar tentunya perlu relasi untuk memperluas pasar usaha, sedangkan warga belajar lainnya mulai merintis usaha dari ketrampilan yang sudah dimiliki.

Salah satu warga belajar menjelaskan bahwa dia tidak hanya mendapatkan teman baru namun juga keluarga baru. Menurutnya, warga belajar dan narasumber yang bergabung dalam pelatihan tersebut adalah keluarga baru baginya. Warga belajar tersebut mengakui bahwa dia mendapatkan dukungan yang kuat untuk selalu berusaha menjadi lebih baik dari keluarga barunya. Warga belajar yang mengikuti kegiatan pelatihan ini berasal dari berbagai kecamatan yang ada di Kabupaten Wonogiri, sehingga banyak dari warga belajar tersebut belum saling mengenal. Oleh karena itu, setelah mengikuti kegiatan pelatihan selama 2 bulan mulai terjalin hubungan yang baik antar warga belajar. Warga belajar juga harus bisa mencari teman baru dan mitra untuk perluasan usaha atau pemasaran produk dan jasa yang dimilikinya. Dengan demikian, penambahan relasi merupakan salah satu bentuk dari awalnya terjadinya sebuah solidaritas pada kelompok tersebut. Penambahan relasi yang dirasakan oleh warga belajar tidak hanya berperan dalam perluasan mitra usaha namun juga pemberi motivasi untuk selalu menjadi lebih baik.

Berdasarkan pembahasan terkait dengan hasil program dapat disimpulkan bahwa hasil program pada Pondok Komunitas Belajar mengacu pada indikator pemberdayaan yang diperoleh dari berbagai kajian teori yang relevan. Hasil program pada program Pondok Komunitas yang merupakan suatu upaya pemberdayaan masyarakat ini meliputi: penambahan pengetahuan dan ketrampilan, adanya motivasi untuk meningkatkan pengetahuan dan ketrampilan, penambahan relasi, dan adanya kegiatan usaha.

Faktor Keberhasilan Pemberdayaan

Pedagang Pasar Tradisional dalam Pondok Komunitas Belajar

Keberhasilan program tercapai apabila hasil dari program sesuai dengan indikatorindikator yang sudah direncanakan sebelumnya. Program Pondok Komunitas Belajar adalah salah satu program yang diselenggarakan oleh SKB Kabupaten Wonogiri. Keberhasilan suatu program pada SKB adalah dinilai dari kebermanfaatan program bagi masyarakat karena salah satu tugas dari SKB yaitu mampu melayani kebutuhan masyarakat. Hal ini sesuai dengan kajian teori yang menjelaskan bahwa Community Learning Center dibentuk untuk membuat program baru yang sesuai dengan kebutuhan masyarakat. Community Learning Center dapat melakukan program apapun asalkan melayani kebutuhan masyarakat. Seperti halnya SKB sebagai salah satu unit pelaksana pendidikan non-formal membuka berbagai pelayanan pendidikan non-formal baik yang disesuaikan dengan program pemerintah maupun program yang dikembangkan sesuai dengan kebutuhan masyarakat.

SKB berkonsep pada Community Learning Center sebagai tempat yang menghubungkan ketiga lingkungan belajar di masyarakat yaitu sekolah, keluarga, dan masyarakat dan menyelenggarakan berbagai program pendidikan non formal yang disesuaikan dengan kebutuhan masyarakat. UNESCO menggambarkan kondisi Commnity Learning Center di Indonesia. UNESCO (2011, p.29) menyatakan bahwa

"CLCs in Indonesia were initially introduced by the Ministry of National Education to manage learning resources provided for non-formal education that were previously offered through various independent non-formal programmes. The introduction of a new, one-roof, institution in 1998 was aimed at achieving two main purposes. The first was to better manage and use more efficiently extant learning resources. It was very difficult to manage all learning resources distributed to various independent programmes. The second purpose was to be able to provide better technical supervision for all nonformal education programmes."

Berdasarkan pernyataan tersebut diketahui bahwa Community Learning Center di Indonesia diperkenalkan oleh Kementrian Pendidikan yang mengelola sumber belajar yang tersedia untuk pendidikan non formal yang sebelumnya ditawarkan melalui 


\section{Jurnal Pendidikan dan Pemberdayaan Masyarakat, 4 (2), November 2017 - 211 \\ Marta Dwi Ningrum, S. Sujarwo}

berbagai program pendidikan non formal di lembaga lain.. Hal tersebut bertujuan untuk mencapai dua tujuan utama: pertama, mengelola dan menggunakan sumber belajar secara efisien. Kedua, memberikan pengawasan teknis untuk semua program pendidikan non formal agar menjadi lebih baik.

Penjelasan tersebut menegaskan bahwa sebagai salah satu Community Learning Center, SKB harus mampu mengelola dan menggunakan sumber belajar secara efisien dan memberikan pengawasan teknis untuk semua program pendidikan non formal agar menjadi lebih baik. Community learning center adalah tempat yang menghubungkan beberapa layanan di masyarakat terkait dengan pendidikan yaitu sekolah, keluarga, dan masyarakat (Kit, 2012, p.3). Su dan Feng (2014, p.220), community learning includes all occurrences of learning through individuals' engagement in the community in various forms and thus includes community service. Apabila dikaitkan dengan program Pondok Komunitas Belajar maka program ini merupakan salah satu program baru yang dirumuskan oleh SKB Kabupaten Wonogiri untuk melayani kebutuhan pendidikan masyarakat. Dengan demikian, SKB Kabupaten Wonogiri harus mampu mengelola dan menggunakan sumber belajar secara efisien dan memberikan pengawasan teknis untuk semua program pendidikan non formal termasuk dalam program Pondok Komunitas Belajar ini.

Berdasarkan hasil penelitian, dapat diketahui bahwa SKB Kabupaten Wonogiri sudah mampu mengelola program pendidikan nonformal yang menggunakan sumber belajar secara efisien. Program Pondok Komunitas Belajar yang diselenggarakan mampu memenuhi kebutuhan sasaran program dan menggunakan sumber belajar dengan tepat. Hal ini dibuktikan dengan warga belajar mudah memahami materi yang diberikan dalam kegiatan pelatihan yang diselenggarakan pada program ini.

Warga belajar mampu memahami dan menggunakan sumber belajar yang disediakan oleh penyelenggara program. Selain sumber belajar, narasumber mengunakan metode dan strategi pembelajaran yang tepat bagi warga belajar. Metode pembelajaran dan strategi pembelajaran yang digunakan mampu memberikan kemudahan bagi warga belajar dalam mempelajari materi yang diberikan. Komposisi pembelajaran dengan memperbanyak praktek dibandingkan teori membuat warga belajar dapat langsung mempraktekkan materi yang disampaikan. Hal ini sesuai dengan konsep pembelajaran learning by doing, yaitu belajar sambil melakukannya. Strategi pembelajaran sangat tepat bagi orang dewasa yang harapannya warga belajar lebih mudah untuk mengaplikasikan ketrampilan tersebut.

Konsep pendidikan orang dewasa juga terlihat jelas dalam penerapan proses pembelajaran pada program ini. Narasumber mampu memberikan kenyamanan pada warga belajar pada saat proses pembelajaran. Dengan demikian, diketahui bahwa SKB Kabupaten Wonogiri melaksanakan tugas dalam mengelola dan menggunakan sumber belajar secara efisien.

SKB Kabupaten Wonogiri melaksanakan kegiatan monitoring dan evaluasi untuk program ini yang dilaksanakan oleh narasumber. Narasumber melakukan monitoring dan evaluasi seiring dengan pelaksanaan proses pembelajaran. Kegiatan monitoring dan evaluasi ini dilakukan untuk mengetahui perkembangan pengetahuan maupun ketrampilan warga belajar dan pelaksanaan program. Hasil dari kegiatan monitoring dan evaluasi ini untuk mengetahui pelaksanaan program yang sudah dijalankan dan untuk menjadi pedoman agar pelaksanaan program selanjutnya menjadi lebih baik.

Nilai yang dihasilkan oleh warga belajar menentukan kelulusan warga belajar. Warga belajar yang lulus berarti sudah memiliki pengetahuan dan ketrampilan yang diberikan dan sebaliknya. Salah satu indikator keberhasilan program yang dirumuskan adalah warga belajar mampu menguasai pengetahuan dan ketrampilan yang diberikan. Indikator lain yang digunakan yaitu warga belajar mampu mengaplikasikan pengetahuan dan ketrampilan yang diberikan pada kehidupannya.

Penyelenggara sebaiknya tidak hanya mengevaluasi hingga pada tahap tersebut, namun setelah program pondok komunitas belajar selesai, penyelenggara perlu meng- 


\section{Jurnal Pendidikan dan Pemberdayaan Masyarakat, 4 (2), November 2017 - 212 Marta Dwi Ningrum, S. Sujarwo}

evaluasi kebermanfaatan program bagi warga belajar. Berdasarkan hasil penelitian terkait dengan hasil program, diketahui bahwa warga belajar sudah mampu memanfaatkan dan menggunakan ketrampilan yang dimiliki untuk kegiatan usaha. Hasil wawancara yang diungkapkan oleh Ketua program Pondok Komunitas Belajar menunjukkan bahwa penyelenggara program menilai program ini cukup berhasil dengan presentase $70 \%$.

Keberhasilan program ini tercapai karena adanya berbagai faktor yang mempengaruhinya. Dari penjelasan di atas maka dapat diketahui bahwa SKB Kabupaten Wonogiri sudah mampu berperan sebagai Community Learning Center yaitu sebagai tempat yang menghubungkan ketiga lingkungan belajar di masyarakat yaitu sekolah, keluarga, dan masyarakat dan menyelenggarakan berbagai program pendidikan non formal yang disesuaikan dengan kebutuhan masyarakat. SKB Kabupaten Wonogiri menyelenggarakan program pendidikan non formal yaitu Pondok Komunitas Belajar. SKB Kabupaten Wonogiri sudah mampu mencapai tujuan dari Community Learning Center yang dirumuskan oleh UNESCO yaitu pertama, mengelola dan menggunakan sumber belajar secara efisien. Kedua, memberikan pengawasan teknis untuk semua program pendidikan non-formal agar menjadi lebih baik. SKB Kabupaten Wonogiri sudah mampu memenuhi kedua hal tersebut. Hal ini dibuktikan dengan keberhasilan program Pondok Komunitas Belajar sebagai program pendidikan non formal yang diselenggarakan oleh SKB ini.

Berdasarkan hasil penelitian, peneliti menyimpulkan bahwa faktor-faktor yang mempengaruhi keberhasilan program Pondok Komunitas Belajar Kabupaten Wonogiri adalah: adanya perencanaan program, motivasi belajar warga belajar tinggi, ketepatan materi dan metode pembelajaran, narasumber yang berkompeten dan penggunaan strategi pembelajaran yang tepat, serta sarana dan prasarana yang memadai. Keberhasilan program tidak hanya dipengaruhi oleh penyelenggara program namun juga respon dari warga belajar dalam mengikuti program tersebut. Hal ini berhubungan dengan peran penyelenggara, narasumber dan warga belajar yang saling berinteraksi secara bersama-sama untuk mencapai tujuan bersama.

Penyelenggara mampu merancang perencanaan program, narasumber berperan dalam memilih dan menggunakan materi, media, metode dan strategi pembelajaran yang tepat. Sedangkan warga belajar memiliki motivasi belajar yang tinggi. Ketiga peran tersebut merupakan tiga faktor utama yang mempengaruhi keberhasilan program Pondok Komunitas Belajar yang diselenggarakan oleh SKB Kabupaten Wonogiri. Namun, dalam keberhasilan program tersebut masih terdapat beberapa kekurangan dalam pelaksanaan program yang perlu diperbaiki dan diperhatikan oleh penyelenggara. Dengan demikian, penyelenggara perlu memperbaikii kekurangan pada pelaksanaan pemberdayaan pedagang pasar tradisional dalam pondok komunitas belajar ini, sehingga pelaksanaan program pondok komunitas belajar pada periode selanjutnya lebih baik.

\section{SIMPULAN}

Pemberdayaan sebagai upaya dan solusi dalam mengatasi permasalahan dan memenuhi kebutuhan masyarakat. Penyelenggaraan pemberdayaan pedagang pasar tradisional dalam pondok komunitas belajar di SKB Kabupaten Wonogiri di dasarkan pada pemenuhan kebutuhan dan mengatasi permasalahan di Kabupaten Wonogiri terkait dengan: (a) kondisi pasar tradisional belum mampu bersaing dengan pasar modern; (b) Pasar Wonogiri memiliki image negatif sebagai lokalisasi prostitusi Pekerja Seks Komersial (PSK) di Kabupaten Wonogiri. dan (c) pedagang pasar tradisional Kabupaten Wonogiri memiliki tingkat pendidikan yang rendah.

Pemberdayaan dapat dilakukan melalui kegiatan pelatihan yang disesuaikan dengan kebutuhan sasaran program. Pemberdayaan pedagang pasar tradisional dalam pondok komunitas belajar di SKB Kabupaten Wonogiri dilaksanakan melalui kegiatan pelatihan tata boga dan tata rias. Kegiatan pada masing-masing pelatihan dilaksanakan selama 2 bulan sebanyak 16 pertemuan. Kegiatan pelatihan yang diselenggarakan berorientasi pada kewirausahaan, harapannya 


\section{Jurnal Pendidikan dan Pemberdayaan Masyarakat, 4 (2), November 2017 - 213 \\ Marta Dwi Ningrum, S. Sujarwo}

ketrampilan yang dimiliki warga belajar setelah mengikuti pelatihan dapat dijadikan sebagai bekal dalam melakukan kegiatan usaha. Materi yang disampaikan merupakan materi dasar berupa teknik memasak aneka kue dan teknik merias pengantin adat jawa. Materi disampaikan dengan metode ceramah, praktek dan diskusi. Narasumber menerapkan strategi pembelajaran orang dewasa yaitu learning by doing. Dengan demikian, warga belajar dapat mempraktekkan secara langsung terkait dengan materi yang sudah didapatkan.

Hasil pemberdayaan berkaitan dengan perubahan pengetahuan, ketrampilan, sikap, dan kemandirian individu maupun kelompok di masyarakat. Hasil penyelenggaraan pemberdayaan pedagang pasar tradisional dalam pondok komunitas belajar di SKB Kabupaten Wonogiri meliputi: (a) penambahan pengetahuan dan ketrampilan terkait membuat aneka kue kering dan merias pengantin adat Jawa; (b) adanya motivasi untuk menambah pengetahuan dan ketrampilan yang sudah dimiliki, hal ini ditandai adanya warga belajar yang ingin melanjutkan pelatihan ke jenjang lebih tinggi. (c) penambahan relasi, warga belajar memperoleh teman baru baik dari teman-teman pelatihan maupun dari pihak SKB Kabupaten Wonogiri. dan (d) kegiatan usaha, warga belajar mulai memanfaatkan ketrampilan baru yang sudah dimilikinya.

Keberhasilan program pemberdayaan berkaitan dengan perencanaan program, kompetensi narasumber, motivasi belajar warga belajar, dan kesesuaian materi serta metode pembelajaran. Faktor keberhasilan penyelenggaraan pemberdayaan pedagang pasar tradisional dalam pondok komunitas belajar di SKB Kabupaten Wonogiri meliputi: adanya perencanaan program, motivasi belajar warga belajar tinggi, ketepatan materi dan metode pembelajaran, narasumber yang berkompeten dan penggunaan strategi pembelajaran yang tepat, sarana dan prasarana yang memadai.

\section{DAFTAR PUSTAKA}

BPS Kabupaten Wonogiri. (2014). Presentase penduduk berumur 15 tahun ke atas yang bekerja menurut lapangan pekerjaan utama di Kabupaten Wonogiri. Diunduh dari wonogirikab.bps.go.id pada tanggal 15 Mei 2016, pukul 15.40 WIB.

BPS Kabupaten Wonogiri. (2014). Presentase penduduk umur 10 tahun ke atas menurut pendidikan tertinggi yang ditamatkan di Kabupaten Wonogiri Tahun 2013-2014. Diunduh dari wonogirikab.bps.go.id pada tanggal 15 Mei 2016, pukul 16.05 WIB.

Budiono, P. (2005). Pendampingan perempuan pedagang pasar tradisional melalui kredit mikro (Studi kasus koperasi Bagor Semarang). Diunduh dari http://eprints.undip.ac.id pada tanggal 12 Maret 2017 pada pukul 13.19 WIB.

Evans, R., Kurantowicz, E., \& Lucio, E. (2016). Researching and transforming adult learning and communities. Netherlands: Sense Publisher.

Ife, J., \& Tesoriero, F. (2014). Community development alternatif pengembangan masyarakat di era globalisasi. Yogyakarta: Pustaka Pelajar.

Kamil, M. (2010). Model pendidikan dan pelatihan (Konsep dan aplikasi). Bandung: Alfabeta.

Karim, MR., Huda, KZ., \& Khan, RS. (2012). Significance of training and post training evaluation for employee effectiveness: An empirical study on Sainsbury's Supermarket Ltd, UK. International Journal of Business and Management. 7,(18):141-148

Kasmel, A. \& Anderson, P.T (2011). Measurement of community empowerment in three community programs in Rapla (Estonia). International Journal of Environmental Research and Public Health,8, 799-817.

Kit, R. (2012). The community learning center. Diunduh dari www.education.gouv.qc.ca pada tanggal 14 Mei 2016, pukul 17.05 WIB.

Miles, M. B., Huberman, A.M., \& Saldana, J. (2014). Qualitative data analysis: A methods sourcebook. Thousand Oaks, CA: Sage. 


\section{Jurnal Pendidikan dan Pemberdayaan Masyarakat, 4 (2), November 2017 - 214 \\ Marta Dwi Ningrum, S. Sujarwo}

Miradj, S., \& Sumarno, S. (2014). Pemberdayaan masyarakat miskin, melalui proses pendidikan nonformal, upaya meningkatkan kesejahteraan sosial di Kabupaten Halmahera Barat. JPPM (Jurnal Pendidikan dan Pemberdayaan Masyarakat), 1(1), 101 112.

doi:http://dx.doi.org/10.21831/jppm.vii1 .2360

Prastyawan, A., Suryono, A., Soeaidy, M.S., \& Muluk, K. (2015). Revitalization of traditional markets into a modern market in the perspective of local governance theory. IOSR Journal Of Humanities And Social Science, 20, (9): o1-06.

Sadino, \& Joesron, A.S. (2014). Pasar tradisional versus pasar modern di daerah perkotaan (Studi kasus: Kecamatan Gondokusuman Kabupaten Yogyakarta). 10(2). 205 - 217. Retrieved fromhttp://ejournal.undip.ac.id.

Sarwoko, E. (2008). Dampak keberadaan pasar modern terhadap kinerja pedagang pasar tradisional di wilayah Kabupaten Malang. Jurnal Ekonomi Modernisasi. Vol 4(2) : 97-115.

Shofwan, I. (2013). Pendidikan alternatif komunitas belajar Qoryah Thayyibah di Salatiga Jawa Tengah. Tesis. Universitas Negeri Yogyakarta.

Saugi, W., \& Sumarno, S. (2015). Pemberdayaan perempuan melalui pelatihan pengolahan bahan pangan lokal. JPPM (Jurnal Pendidikan dan Pemberdayaan Masyarakat), 2(2), 226 238.

doi:http://dx.doi.org/10.21831/jppm.v2i 2.6361

Soetomo. (2013). Pemberdayaan masyarakat. Yogyakarta:Pustaka Pelajar.

Su, Y. \& Feng, L. (2014). Community service as a lifelong learning practice: themes and hypotheses. International Journal of Humanities and Social Science,4, (4): 219-226.

Suharto, E. (2010). Membangun masyarakat menberdayakan rakyat: Kajian strategis pembangunan kesejahteraan sosial dan pekerjaan sosial. Bandung : PT Refika Aditama.

Sulistiyani, A.T. (2004). Kemitraan dan model-model pemberdayaan. Yogyakarta: Gava Media.

Suparjan \& Suyatno, H. (2003). Pengembangan masyarakat dari pembangunan sampai pemberdayaan. Yogyakarta: Aditya Media.

UNESCO. (2011). Sustainability of community learning centres: community ownership and support Asia-Pasific regional actiom research studies. Diunduh dari unesdoc.unesco.org/images/o021/o021 46/214655E.pada tanggal 14 Mei 2016, pukul 18.35 WIB.

Zubaidi. (2006). Pendidikan berbasis masyarakat upaya menawarkan solusi terhadap berbagai program sosial. Yogyakarta:Pustaka Pelajar. 